\title{
Yield and quality of bell pepper fruits irrigated with magnetically treated water
}

\author{
Marcelo Zolin Lorenzoni' ${ }^{1}$, Roberto Rezende ${ }^{2}$, Cássio de Castro Seron ${ }^{3}$, Álvaro Henrique \\ Cândido de Souza 4 \\ ${ }^{1}$ Instituto Federal Goiano, Campus Posse, Posse, Goiás, Brasil. E-mail: marcelo.lorenzoni@ifgoiano.edu.br \\ ${ }^{2}$ Universidade Estadual de Maringá, Campus Maringá, Maringá, Paraná, Brasil. E-mail: rrezende@uem.br \\ ${ }^{3}$ Universidade Estadual de Mato Grosso do Sul, Unidade Universitária de Cassilândia, Cassilân dia, Mato Grosso do Sul, Brasil. E- \\ mail: cassio.seron@uems.br \\ ${ }^{4}$ Instituto Federal Goiano, Campus Cristalina, Cristalina, Goiás, Brasil. E-mail: alvaro.candido@ifgoiano.edu.br \\ Received: 04/05/2021; Accepted: 22/06/2021.
}

\begin{abstract}
The application of magnetically treated water is a valuable technique for crop irrigation to enhance the yield and quality of agricultural products. This study aims to evaluate the effect of irrigation water depths and the application of water with and without magnetic treatment on the yield and quality of bell pepper fruits in a controlled environment, verifying the effect of magnetically treated water on soil water retention. Two experiments were conducted in the Irrigation Technical Center of the Univers idade Estadual de Maringá, Maringá/PR; the first on Summer 2017-2018, and the second on Winter-Spring 2018. A randomized block design with a factorial scheme 3 $\mathrm{x} 2$ with four repetitions was used for the first experiment and a 2 x 2 scheme with six repetitions for the second. The first factor was the water replacement levels (based on the crop evapotranspiration), and the second the irrigation water treatment, with or without magnetic treatment. The yield and number of fruits were determined after six and four harvests in the first and second experiments. Quality characteristics (soluble solids level, $\mathrm{pH}$, and titratable acidity) were evaluated from three fruits of each plant. The data was submitted to the Tukey test ( $p \leq$ 0.05). It was verified that the application of magnetically treated water did not influence yield. However, it increased the levels of soluble solids and $\mathrm{pH}$. To evaluate the effect of applying magnetically treated water on soil retention, 12 pots filled with soil and without plants were used. An increase in the gravimetric soil moisture using magnetically treated water was perceived, demonstrating higher water retention when using the irrigation method.
\end{abstract}

Keywor ds: magnetic field, Capsicum annuum L., magnetism, number of fruits, production.

\section{Produtividade e qualidade de frutos de pimentão irrigado com água tratada magneticamente RESUMO}

A aplicação de água tratada magneticamente é uma tecnologia valiosa na irrigação das culturas para melhorar o rendimento e a qualidade dos produtos agrícolas. Objetivou-se com este estudo avaliar o efeito de lâminas de irrigação e aplicação de água com e sem tratamento magnético na produtividade e qualidade de frutos de pimentão conduzidos em ambiente protegido e verificar o efeito da aplicação de água tratada magnet icamente sob a retenção no solo. Dois experimentos foram conduzidos no Centro Técnico de Irrigação da Universidade Estadual de Maringá, Maringá/PR, sendo o primeiro no verão (2017-2018) e o segundo no inverno e primavera (2018). O delineamento experimental foi em blocos ao acaso em esquema fatorial 3 x 2 com 4 repetições e 2 x 2 com 6 repetições para o primeiro e segundo experimento, respectivamente. O primeiro fator consistiu em níveis de reposição da água (baseados na evapotrans piração da cultura)e o seg undo fator consis tiu no tratamento da água de irrigação com e sem tratamento magnético. A produtividade e o número de frutos foram determinados após seis e quatro colheitas no primeiro e no segundo experimento, respectivamente. As características de qualid ade (teor de sólidos solúveis, $\mathrm{pH}$ e acidez titulável) foram avaliados em três frutos de cada planta. Os dados foram submetidos ao teste de Tukey $(p \leq 0,05)$. Verificou-se que aplicação de água tratada magneticamente não influenciou a produtividade, no entanto, sua aplicação aumentou os teores de sólidos solúveis e $\mathrm{pH}$. Para verificar o efeito da aplicação de água tratada magneticamente sob a retenção no solo foram utilizados 12 vasos preenchidos com solo e sem plantas, foi constatada aumento da umidade gravimétrica no solo com a aplicação de água com tratamento magnético, demostrando maior retenção de água quando submetido a essa condição de irrigação.

Palavras-chave: campo magnético, capsicum annuum L., magnetismo, número de frutos, produção. 


\section{Introduction}

Vegetable production has gradually increased during the last years due to increasing demand and their health benefits. Thus, it needs technologies that favor the production of crops regarding some regional and seasonal limitations, such as the use of a controlled environment, hybrid seeds, efficient irrigation systems, and fertigation (Lorenzoni et al., 2020).

Bell pepper (Capsicum annuum L.) pertains to the Solanaceae family and is cultivated in the Brazilian territory. According to Lopes et al. (2018), bell pepper is among the ten most important vegetables in the Brazilian market and the third most cultivated Solanaceae, only behind tomato and potato. FAO (2019) reports that the estimated world production was 38 million tons of fruits in a planted area of 1.99 million hectares. Such numbers justify the search for new technologies that enhance water use in agricultural production. The increase in irrigation and food production efficiency is crucial to develop plants with lower water volume applied (Putti et al., 2013). According to Sayed (2014), physical methods to stimulate plant growth, such as controlled environment, irrigation systems, and magnetic water treatment, are increasingly popular because they are less harmful to the environment.

Studies demonstrated that magnetically treated water favors yield increase and quality of products (Putti et al., 2013). These studies used magnetically treated water in irrigation to foster yield and products quality and considered it a valuable technology for crop irrigation (Aguilera e Martín, 2016; Generoso et al., 2017). Ahmed \& El-Kader (2016) found an increase in the vegetative growth and production of Solanaceae in a potato crop with magnetically treated water in four water levels, considering the field capacity.

Thus, the conduction of more specific studies about magnetism is fundamental because, besides the scarcity of experiments, the skepticism regarding the magnetic treatment is caused mainly by the absence of scientific papers on the subject. The application of this technology involves a series of experimental conditions, such as exposition period and induction level, frequencies, intensities, and types of electromagnetic fields (Maheshwari e Grewal, 2009).

Therefore, this study aims to evaluate the benefits of irrigation with magnetically treated water and irrigation replacement levels (based on the crop evapotranspiration) on the yield and quality of bell pepper fruits, hybrid Magali R, in a controlled environment, verifying the effect of magnetically treated water on soil water retention.

\section{Material and Methods}

The experiments were conducted in a controlled environment located at the Centro Técnico de Irrigação (CTI) of the Universidade Estadual de Maringá (UEM), city of Maringá, state of Paraná (latitude 2325'57' S; longitude 51 $57^{\prime} 08^{\prime \prime} \mathrm{W}$; and altitude of $542 \mathrm{~m}$ ). The region climate is $\mathrm{Cfa}$ (warm temperate) according to the Köppen classification (Alvares et al., 2013).

The controlled environment has $30 \mathrm{~m}$ in length, $7 \mathrm{~m}$ in width, and $3.5 \mathrm{~m}$ in height, with an arched roof covered with polyethylene film $(150 \mu \mathrm{m})$ and an anti-aphid white net. The two experiments correspond to the following cultivation periods: the first between 20/11/2017 (transplant) and 19/03/2018 (last harvest) (summer; 120 days), and the second between 15/06/2018 (transplant) and 15/11/2018 (last harvest, winter-spring; 150 days).

A randomized block design was used in both experiments. The factorial scheme $3 \times 2$ was used in the first experiment, resulting in six treatments with four repetitions. The first factor consisted of three water replacement depths based on the crop evapotrans piration (50\%, 75\%, and $100 \%$ of ETc). The second factor was the application of irrigation water with or without magnetic treatment. The treatments application started 19 days after the transplant (DAT) of the seedlings.

The factorial scheme $2 \times 2$ was adopted for the second experiment, resulting in 4 treatments with six repetitions. The first factor consisted of two water replacement depths ( $75 \%$ and $100 \%$ of ETc), and the second factor was the application of two irrigation water treatments (with or without magnetic treatment). The treatments started 20 DAT of the seedlings. The water replacement level of $50 \%$ ETc was not used in the second experiment due to the intense water stress suffered by bell pepper plants during the conduction of the second experiment, resulting in a low crop yield compared with the levels of 75 and $100 \%$ ETc.

In both experiments, the bell pepper seedlings were planted in polyethylene trays filled with a commercial substrate (pine bark) for vegetables of the brand Mecplant. Bell pepper seeds, hybrid Magali R., were seeded in the trays, depositing one seed per cell. The seedlings were transplanted to the flowerbeds $(3 \mathrm{~m} \times 0.5$ $\mathrm{m})$ when they presented four or six defined leaves. Six plants were allocated in each flowerbed with a distance between lines of $1 \mathrm{~m}$, and $0.5 \mathrm{~m}$ between plants. The extremities were considered as a border.

The experimental site soil is classified as Nitossolo Vermelho distroférrico (Embrapa, 2013). Its chemical characteristics in the layers between $0-10 \mathrm{~cm}$ are presented by Lorenzoni et al. (2020). The soil was turned over with a rotary hoe for the first soil analysis, performed in the summer crop. Liming was performed 60 days before the transplant. For the base fertilizing, in the 
first experiment, 20 days before the transplant were applied $110 \mathrm{~kg} \mathrm{ha}^{-1}$ of urea (17 g per flowerbed), $265 \mathrm{~kg}$ $\mathrm{ha}^{-1}$ of $\mathrm{KCl}$ (40 g per flowerbed), $1110 \mathrm{~kg} \mathrm{ha}^{-1}$ of simple superphosphate (167 g per flowerbed), $3 \mathrm{~kg}$ of organic matter per flowerbed. For the second experiment, fertilizing was conducted 20 days before the transplant based on the second soil analysis, applying $110 \mathrm{~kg} \mathrm{ha}^{-1}$ of urea (17 g per flowerbed), $34 \mathrm{~kg} \mathrm{ha}^{-1}$ of $\mathrm{KCl}(5 \mathrm{~g}$ per flowerbed), $220 \mathrm{~kg} \mathrm{ha}^{-1}$ of simple superphosphate (33 $\mathrm{g}$ per flowerbed), and $3 \mathrm{~kg}$ of organic matter per flowerbed. The doses of $\mathrm{N}\left(155 \mathrm{~kg} \mathrm{ha}^{-1}\right)$ and $\mathrm{K}\left(110 \mathrm{~kg} \mathrm{ha}^{-1}\right)$ followed the recommendations of Lorenzoni et al. (2016), and the other doses were based on the recommendations of Trani (2014).

During the experiments, fertigation with nitrogen (calcium nitrate) and potassium $(\mathrm{KCl})$ was performed every 15 days, using the doses recommended by Lorenzoni et al. (2016). According to the absorption march, the nutrient amount was split, following Fontes et al. (2005).

A drip micro-irrigation was used, with a uniformity coefficient $(\mathrm{Cu})$ of $96 \%$, which is considered excellent (Frizzone et al., 2012), evaluated in field conditions. Each flowerbed had a lateral polyethylene line $(16 \mathrm{~mm}$ diameter) with 12 self-compensating drippers with $4 \mathrm{~L}$ $\mathrm{h}^{-1}$ flow rate, with $0.25 \mathrm{~m}$ between them. The system trigger was attached to a centrifugal pump of $0.5 \mathrm{cv}$ potency connected to two reservoirs, one with a capacity of $500 \mathrm{~L}$, used to store water without magnetic treatment and another with a total of $1000 \mathrm{~L}$ to store magnetically treated water.

To magnetically treat the water, the magnetizer Sylocimol Residence (Timol Industry and Trade of magnetic products) was used, which has the capacity of treating 1000 liters per hour. The magnetizer is made with alternated magnets protected by a stainless-steel cylinder, with $0.1 \mathrm{~m}$ diameter and $0.165 \mathrm{~m}$ height. The equipment has a magnetic field of 1000 Gauss, evaluated at the Department of Physics of the UEM with a LakeShore 425 Gaussmeter.

The device was installed at the center of the 1000 liters reservoir used to irrigate the seedling of this treatment. The application of the treatments was divided into two parts: first, the reservoir with the magnetically treated water register was opened, and water was allowed to circulate in the system for 2 minutes to fill the tubes with the treated water. After this process, the registers of the irrigated parcels with the magnetically treated water were opened. They were kept open during the period of irrigation of each treatment (water depth based on ETc). After the irrigation with the treated water, the process was repeated with the water without treatment for the irrigation of this treatment.

Irrigation management for water replacement was performed based on the crop evapotranspiration values
(ETc). The reference evapotranspiration (ETo) calculation was performed using the Penman-Monteith methodology proposed by Allen et al. (1998). The meteorological data were obtained from an automatic climatological station installed inside the controlled environment with a datalogger capable of collecting and storing data every 2 seconds, providing the mean for each variable every 30 minutes.

The crop evapotranspiration, in $\mathrm{mm} \mathrm{day}^{-1}$, was determined by multiplying the reference evapotranspiration (ETo) with the single crop coefficient $(\mathrm{Kc})$. The values of $\mathrm{Kc}$ used are those recommended by Allen et al. (1998), being them: 0.6 (initial phase), 1.05 (intermediate phase), and 0.9 (final phase). The irrigation period to apply the replacement depths of $100 \%, 75 \%$, and $50 \%$ of ETc was measured by dividing the value of ETc by the application intensity in each parcel $\left(\mathrm{ml} \mathrm{min} \mathrm{min}^{-1}\right)$.

To measure yield (YLD) and the number of fruits $(\mathrm{NF})$, the harvest point used was when the fruits reached maximal development before they acquired the characteristic color (red) of cultivars. The four central plants were harvested, considered the useful area, not considering the plants in the borders. Six harvests were conducted during the first experiment, the first 60 DAT and the last 120 DAT. Four harvests were performed in the second experiment, the first 80 DAT and the last 150 DAT.

The YLD (grams per plant) was obtained by determining the commercial fruits of the utile area fresh mass, with lengths higher than six centimeters, without mechanical damages, burns, pests, or diseases. The NF (fruits per plant) was obtained by counting all the commercial fruits harvested. The length and diameter of fruits were measured with a digital caliper. A digital balance $(0.01 \mathrm{~g})$ was used to measure the fruit mass.

Three fruits from each plant, harvested in the first experiment, were stored in a refrigerator for posterior analysis of the soluble solids content ( ${ }^{\circ}$ Brix), titratable acidity (\% citric acid), and $\mathrm{pH}$. The soluble solids content was determined with a refractometer, and $\mathrm{pH}$ with a digital $\mathrm{pH}$ meter, determined by a direct reading of the bell pepper extract. To determine titratable acidity (TA), following the methodology proposed by the Instituto Adolfo Lutz (2008). An aliquot of $20 \mathrm{ml}$ bell pepper extract was pipetted, adding $30 \mathrm{ml}$ of water and three drops of alcoholic phenolphthalein at $1 \%$ (indicator). Titration was conducted with sodium hydroxide at $0.1 \mathrm{~N}$ until the equivalence point.

To verify the effect of the magnetically treated water on soil retention, twelve pots (with a capacity of $21.5 \mathrm{~L}$ ) were used filled with the same soil mass $(5 \mathrm{~kg}$ of the soil of each experimental area). A drainage system with gravel and the non-woven fabric was built. A perforated PVC tube (50 mm diameter and $10 \mathrm{~cm}$ length) was inserted 
vertically in each pot center used for water replacement. This system facilitated water distribution in the soil. Hence, no drainage through the holes of the pot base was verified. The pots were placed on stands $(1 \mathrm{~m}$ height) in the controlled environment using a randomized design with two treatments (magnetically treated water and non-treated water) and six repetitions. The water replacement levels were performed with a precision balance $(2 \mathrm{~g})$ during the mornings, aiming to elevate the soil moisture to the initial moisture (storage capacity of $\left.0.39 \mathrm{~g} \mathrm{~g}^{-1}\right)$.

The entire pot mass and the storage capacity were $8450 \mathrm{~g}(8.45 \mathrm{~kg})$. The same experiment was repeated thrice with distinct frequencies: daily for seven days, every three days for two weeks, and every seven days for two weeks. The tabulated data were submitted to analys is of variance at the 5\% probability level using the F-test. The significant data was submitted to the Tukey test $(\mathrm{p} \leq$
0.05). The statistical analyses were performed with the statistical software Sisvar (Ferreira, 2019).

\section{Results and Discussion}

Both experiments registered higher and lower temperatures than values considered favorable for bell pepper cultivation (Figure 1). Values for mean, higher, and lower temperatures recorded inside the controlled environment during the first experiment were 20.3-32.3 ${ }^{\circ} \mathrm{C}, 22.7-42.3^{\circ} \mathrm{C}$, and $14.8-23.3^{\circ} \mathrm{C}$, respectively. In the second experiment, values varied between 12.1-29.4 ${ }^{\circ} \mathrm{C}$ for mean temperature, $17.1-41.8^{\circ} \mathrm{C}$ for the higher temperature, and 4.9-23.5 ${ }^{\circ} \mathrm{C}$ for the lower temperature.

Table 1 shows the summary of the analysis of variance for the variables yield (YLD) and the number of fruits (NF) evaluated during the first and second experiments.

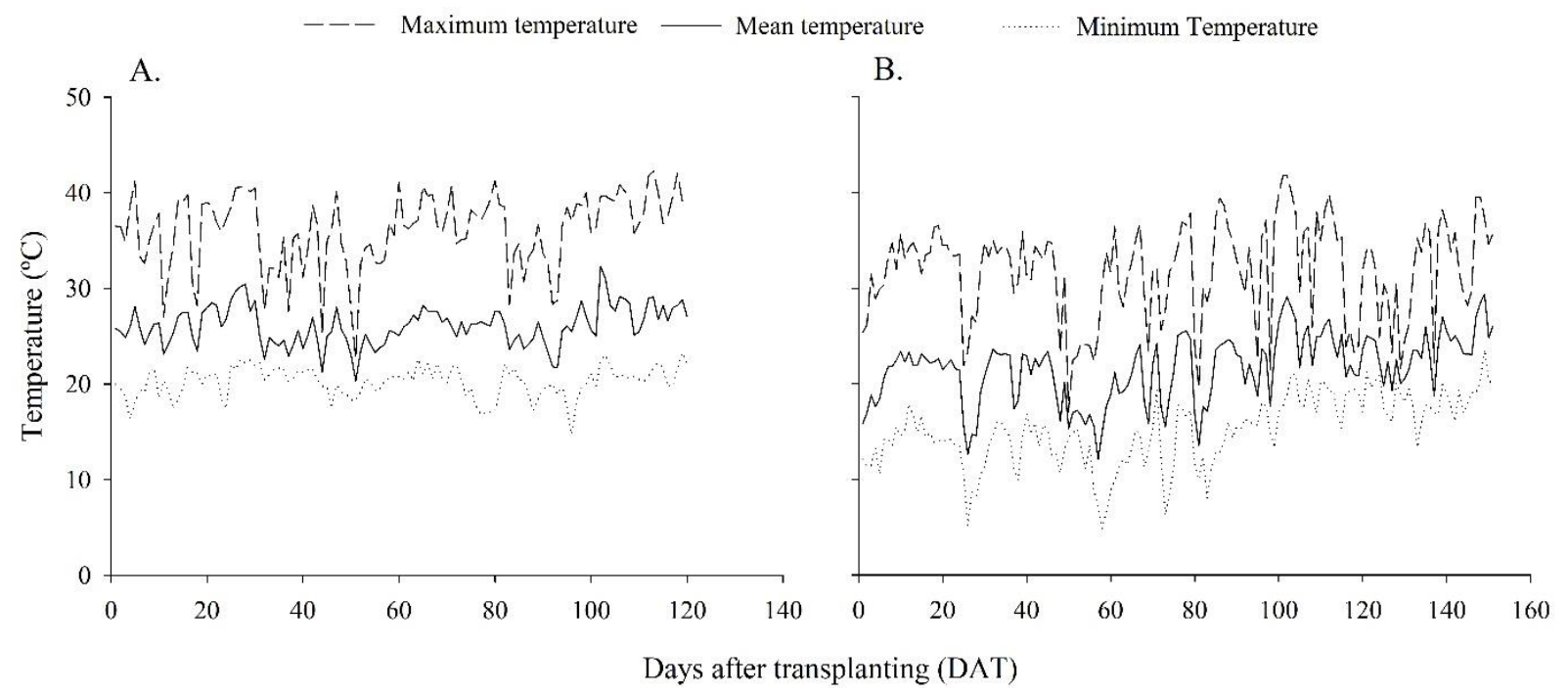

Figure 1. Daily maximum, medium, and minimum temperatures registered inside the controlled environment during the first (A) and the second experiment (B). Maringá-PR, 2018

Table 1. Summary of the analy sis of variance for the variables yield (YLD), and the number of fruits (NF) for irrigated bell pepper cultivation with magnetically treated and non-treated water, and levels of irrigation, soluble solids content (SS), pH, and titratable acidity (TA), evaluated in the first experiment. Maringá-PR, 2018

\begin{tabular}{|c|c|c|c|c|c|c|}
\hline \multirow{2}{*}{ Experiment } & \multirow{2}{*}{ Variable } & \multicolumn{3}{|c|}{ F-values } & \multirow{2}{*}{$\mathrm{CV}(\%)$} & \multirow{2}{*}{$\begin{array}{l}\text { General } \\
\text { mean }\end{array}$} \\
\hline & & Treat. Water (T) & Irrigation levels $(\mathrm{N})$ & $\mathrm{T} \times \mathrm{N}$ & & \\
\hline \multirow{5}{*}{ I } & YLD & $1.19^{\mathrm{ns}}$ & $144.95^{*}$ & $0.79^{\mathrm{ns}}$ & 24.05 & 5222.45 \\
\hline & $\mathrm{NF}$ & $0.73^{\text {ns }}$ & $78.30 *$ & $0.59^{\text {ns }}$ & 19.78 & 117.18 \\
\hline & SS & $5.73 *$ & $2.26^{\mathrm{ns}}$ & $2.96^{\mathrm{ns}}$ & 11.22 & 5.74 \\
\hline & $\mathrm{pH}$ & $11.50 *$ & $11.84 *$ & $0.11^{\mathrm{ns}}$ & 2.34 & 5.65 \\
\hline & TA & $1.97^{\mathrm{ns}}$ & $2.89^{\text {ns }}$ & $3.37^{\mathrm{ns}}$ & 14.24 & 1.99 \\
\hline \multirow{2}{*}{ I } & YLD & $0.57^{\mathrm{ns}}$ & $25.33^{*}$ & $0.93^{\mathrm{ns}}$ & 7.54 & 2728.11 \\
\hline & NF & $2.29^{\mathrm{ns}}$ & $2.64^{\mathrm{ns}}$ & $9.82 *$ & 11.21 & 32.64 \\
\hline
\end{tabular}

*Significant at $5 \%$ de probability; ns not significant at $5 \%$ probability; CV: coefficient of variation. 
According to Filgueira (2003), temperatures must have means between $19-21{ }^{\circ} \mathrm{C}$ for a good yield, and temperatures lower than $15^{\circ} \mathrm{C}$ or higher than $35^{\circ} \mathrm{C}$ can affect the development phases of plants. Besides the extreme temperatures registered during the experimental periods, no losses were verified because they occurred briefly during the day or the night according to the season. Higher or lower temperatures were not constant. The avaliation occurred during the first experiment (120 days cycle) and the second (150 days cycle) for bell pepper cultivation. A significant interaction for the variable NF was perceived only in the second experiment. There was an isolated effect between the irrigation levels for the variables YLD (first and second experiments) and NF (first experiment) $(\mathrm{p} \leq 0.05)$.

The application of the irrigation water depth based on $100 \%$ of the ETc was higher than the 75 and $50 \%$ for the variables YLD and NF (Table 2). For the variable YLD, there was an increase of $266.4 \%$ and $786 \%$, and for NF, a rise of $88.7 \%$ and $273.8 \%$ compared with the replacement levels of 75 and $50 \%$ of the ETc, respectively.

Such results show the bell pepper sensibility to water deficit with a considerable yield loss per plant. Souza et al. (2019) did not verify significant interactions for YLD and NF variables with the application of magnetically treated water and irrigation depths in eggplant cultivation in similar experimental conditions. The authors observed significant responses only to apply irrigation depths for YLD and NF variables and the irrigation level of $100 \%$ ETc that provided the higher values.

In the second experiment, the YLD of bell pepper with a depth of $100 \%$ ETc was $2939.4 \mathrm{~g}$ per plant, higher than the depth based on $75 \%$ ETc, with YLD equal to $2516.8 \mathrm{~g}$ per plant, an increase of $16.8 \%$. Thus, as observed in this study, water deficit caused a restriction in eggplant yield, independently from the water treatment used, with lower values for the variables studied than the hydric supplementation with 100\% ETc (Souza et al., 2019).

Table 2. Mean values of yield (YLD), g per plant, and the number of fruits (NF) of irrigated bell pepper with magnetically treated and non-treated water, and irrigation levels in the first experiment. Maringá-PR, 2018

\begin{tabular}{lll}
\hline \multirow{2}{*}{ Irrigation levels (\% ETc) } & \multicolumn{2}{c}{ Variables } \\
\cline { 2 - 3 } & YLD & NF \\
\hline 50 & $1276.0 \mathrm{C}$ & $52.3 \mathrm{C}$ \\
75 & $3085.4 \mathrm{~B}$ & $103.6 \mathrm{~B}$ \\
100 & $11305.8 \mathrm{~A}$ & $195.5 \mathrm{~A}$ \\
\hline
\end{tabular}

*Means followed by the same letter do not differ statistically from each other. Uppercase letters in the column differ by the Tukey test at $5 \%$ probability.
Similar results of Souza et al. (2019) were found by Seron et al. (2019) for scarlet eggplant cultivation. The authors did not observe significant responses between the water treatment and the ETc levels evaluated. Nevertheless, there were significant responses for the application of irrigation depths for the variables YLD and NF. The irrigation levels of $78 \%$ and $100 \%$ ETc did not differ statistically, permitting strategies that reduce the water depth without lowering yield.

In a study performed by Surendran et al. (2016), there was an increase of $25.8 \%$ in irrigated eggplant yield with magnetically treated water. However, the authors did not find significant differences in applying magnetically treated water in common beans. According to the same authors, water with a huge amount of salt submitted to magnetic treatment and applied in common beans and eggplant cultivation increased the yield of both. The results find by Surendran et al. (2016) support the idea of OspinaSalazar et al. (2018) that the species react in different ways when submitted to magnetically treated water due to the lack of significant responses. In the second experiment, with the finding of a significant interaction for the variable NF (Figure 2), the unfolding is presented regarding water treatment and irrigation levels for variables mentioned.

Significant differences with the application of nontreated water were verified for the irrigation level with $100 \%$ ETc replacement for the variable NF (Figure 2A). Figure 2B shows that the irrigation level with $100 \%$ ETc replacement was higher than the $75 \%$ ETc with nontreated water. According to the results of table 2 and figure 2 , the application of magnetically treated water in bell pepper crops did not present significant effects in the number of fruits, only for the replacement levels based on ETc in both experiments.

The extension of the crop cycle in the second experiment may be related to the temperature conditions during this period. Lower temperatures occurred during the second experiment (Figure 1). Besides, no damages to the crop were verified. The periods with lower temperatures may have contributed to the decrease in plant growth, increasing the crop cycle duration (Filgueira, 2012). None of the quality variables evaluated during the first experiment presented significant interaction (Table 1). A significant response was verified only for the irrigation levels and $\mathrm{pH}$. Regarding water treatment, there was a significant response for $\mathrm{pH}$ and soluble solids (SS).

The application of magnetically treated water increased the soluble solids content $\left(6.05^{\circ}\right.$ Brix $)$ compared with the non-treated water $\left(5.43^{\circ}\right.$ Brix $)$, increasing $11.4 \%$. The soluble solids content is a characteris tic that represents sugars and acids, and higher soluble solids content favors the production. We did not find studies in the literaturethat report the soluble solids values caused by magnetically treated water in bell pepper cultivation. 

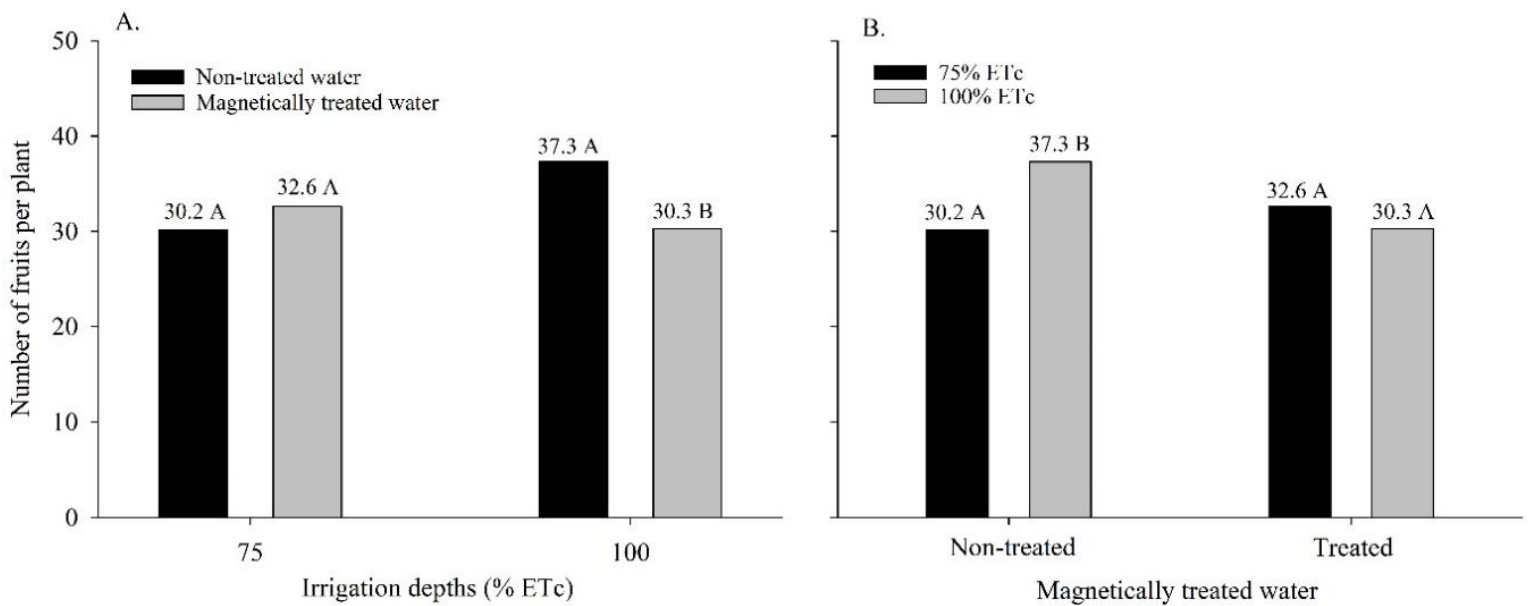

Figure 2. Number of fruits per plant (NF), in the second experiment, for the irrigated bell pepper cultivation with magnetically treated and non-treated water and irrigation levels. Bars with different letters differ by the Tukey test. Maringá-PR, 2018

Table 3. Measures of actual moisture in the pots submitted to magnetically treated and non-treated water for different irrigation frequencies. Maringá-PR, 2018

\begin{tabular}{|c|c|c|c|}
\hline Frequency & Evaluations & Magnetic water treatment & Actual moisture $\left(\mathrm{g} \mathrm{g}^{-1}\right)$ \\
\hline \multirow{14}{*}{ Daily } & \multirow{2}{*}{1} & With & $0.3657 \mathrm{~A}$ \\
\hline & & Without & $0.3644 \mathrm{~A}$ \\
\hline & \multirow{2}{*}{2} & With & $0.3632 \mathrm{~A}$ \\
\hline & & Without & $0.3622 \mathrm{~A}$ \\
\hline & \multirow{2}{*}{3} & With & $0.3643 \mathrm{~A}$ \\
\hline & & Without & $0.3616 \mathrm{~B}$ \\
\hline & \multirow{2}{*}{4} & With & $0.3636 \mathrm{~A}$ \\
\hline & & Without & $0.3617 \mathrm{~B}$ \\
\hline & \multirow{2}{*}{5} & With & $0.3675 \mathrm{~A}$ \\
\hline & & Without & $0.3660 \mathrm{~A}$ \\
\hline & \multirow{2}{*}{6} & With & $0.3557 \mathrm{~A}$ \\
\hline & & Without & $0.3537 \mathrm{~B}$ \\
\hline & \multirow{2}{*}{7} & With & $0.3633 \mathrm{~A}$ \\
\hline & & Without & $0.3624 \mathrm{~A}$ \\
\hline \multirow{8}{*}{ Three days } & \multirow{2}{*}{1} & With & $0.3143 \mathrm{~A}$ \\
\hline & & Without & $0.3092 \mathrm{~B}$ \\
\hline & \multirow{2}{*}{2} & With & $0.2953 \mathrm{~A}$ \\
\hline & & Without & $0.2934 \mathrm{~A}$ \\
\hline & \multirow{2}{*}{3} & With & $0.3165 \mathrm{~A}$ \\
\hline & & Without & $0.3140 \mathrm{~B}$ \\
\hline & \multirow{2}{*}{4} & With & $0.3207 \mathrm{~A}$ \\
\hline & & Without & $0.3172 \mathrm{~B}$ \\
\hline \multirow{4}{*}{ Seven days } & \multirow{2}{*}{1} & With & $0.2629 \mathrm{~A}$ \\
\hline & & Without & $0.2601 \mathrm{~B}$ \\
\hline & \multirow{2}{*}{2} & With & $0.2844 \mathrm{~A}$ \\
\hline & & Without & $0.2810 \mathrm{~B}$ \\
\hline
\end{tabular}

*Means followed by the same letter do not differ statistically from each other.

For the variable $\mathrm{pH}$, the values of 5.74 and 5.55 for the magnetically treated and non-treated water, respectively, presented a significant difference. However, they are still in the range for non-acid fruits, as Gould (1974) established. The same difference occurred for the application of irrigation depths, in which the replacement of $100 \%$ ETc presented a significant lower value $(\mathrm{pH}=5.47)$ compared with the levels of $50 \%(\mathrm{pH}=5.77)$ and $75 \%(\mathrm{pH}=5.71)$ ETc.. Even in the evaluations that did not show significant differences, it was perceived that the mean values are higher with the magnetically treated water. The study of magnetically treated water in irrigation is critical because it can enhance soil moisture conditions and reduce soil water loss (Mostafazadeh-Fard et al., 2011), besides promoting more favorable conditions for plants.

According to Khoshravesh et al. (2011) and Surendran et al. (2016), the reduction in irrigated soil moisture with the magnetically treated water is due to increased water cohesion in soil particles, facilitating its 
fixation to the particles and impeding percolation to deeper layers.

Regarding the frequencies (daily, every three days, and every seven days), it was verified that the water magnetically treated maintained soil moisture in larger intervals between irrigations. This response was perceived in the frequencies of 3 and 7 days; only one evaluation in the frequency of 3 days did not present a significant response.

Mostafazadeh-Fard et al. (2011) recommended the use of magnetically treated water to increase soil moisture. This study showed that irrigation with magnetically treated water significantly increases soil moisture up to $7.5 \%$ compared with non-treated water. Surendran et al. (2016) found higher water retention in soil when irrigated with magnetically treated water. The authors found statistical differences in soil moisture in the first and the second days after irrigation in an eggplant crop.

\section{Conclusions}

The replacement depth of $100 \%$ of the crop evapotranspiration provided a higher yield and number of fruits.

The application of magnetically treated water increased the soluble solids content and $\mathrm{pH}$ values compared with the non-treated water.

The application of magnetically treated water increased gravimetric soil moisture during the days, demonstrating higher soil water retention when submitted to this irrigation water treatment.

\section{Authors' Contribution}

Marcelo Zolin Lorenzoni contributed to the installation of the two experiment, data collection, statistical analysis and writing of the manuscript. Cássio de Castro Seron e Álvaro Henrique Cândido de Souza contributed to the implementation of the two experiment and data collection.

Roberto Rezende was the first author's advisor and contributed to the statistical analysis and advice on the writing and correction of the manuscript.

\section{Acknowledgments}

Authors thank Coordenação de Aperfeiçoamento de Pessoal de Nível Superior - CAPES and Universidade Estadual de Maringá (UEM).

\section{Bibliographic References}

Aguilera, J.G., Martín, R.M. 2016. Água tratada magneticamente estimula a germinação e desenvolvimento de mudas de Solanum lycopersicum L. Revista Brasileira de Agropecuária Sustentável, 6(1), 47-53. DOI: https://doi.org/10.21206/rbas.v6i1.320.

Ahmed, M.E., El-Kader, N.I. 2016. The influence of magnetic water and water regimes on soil salinity, growth, yield and tubers quality of potato plants. Middle East Journal of Agriculture, $\quad 5(2), \quad$ 132-143. https://www.researchgate.net/publication/301548419_The_Inf luence_of_Magnetic_Water_and_Water_Regimes_on_Soil_Sa linity_Growth_Yield_and_Tubers_Quality_of_Potato_Plants. (accessed March 7, 2021)

Allen, R.G., Pereira, L.S., Raes, D., Smith, M., 1998. Crop evapotranspiration: Guidelines for computing crop water requirements. Rome, FAO.

Alvares, C.A., Stape, J.L., Sentelhas, P.C., Gonçalves, J.L.M., Sparovek, G., 2013. Köppen's climate classifcation map for Brazil. Meteorologische Zeitschrift, 22(6), 711-728. DOI: https://doi.org/10.1127/0941-2948/2013/0507.

EMBRAPA. EMPRESA BRASILEIRA DE PESQUISA AGROPECUÁRIA, 2013. Centro Nacional de Pesquisa de Solos. Sistema brasileiro de classificação de solos, terceira ed. Rio de Janeiro, Embrapa, 353p.

FAO. FOOD AND AGRICULTURE ORGANIZATION OF THE UNITED NATIONS. 2019. FAOSTAT - Chillies and peppers, green. http://www.fao.org/faostat/en/\#data/QC. (accessed June 18, 2021)

Ferreira, D.F., 2019. SISVAR:a computer analy sis system to fixed effects split plot type designs. Revista Brasileira de Biometria, 37(4), 529-535. DOI: https://doi.org/10.28951/rbb.v37i4.450

Filgueira, F.A.R., 2012. Novo manual de olericultura: Agrotecnologia moderna na produção e comercialização de hortaliças, terceira ed. Editora UFV, Viçosa.

Filgueira, F.A.R. 2003. Solanáceas: agrotecnologia moderna na produção de tomate, batata, pimentão, pimenta, berinjela e jiló. UFLA, Lavras.

Frizzone, J.A., Freitas, P.S.L., Rezende, R., Faria, M.A., 2012. Microirrigação: gotejamento e microaspersão. Eduem, M aringá.

Fontes, P.C.R., Dias, E.N., Graça, R.N. 2005. Acúmulo de nutrientes e método para estimar doses de nitrogênio e potássio na fertirrigação do pimentão. Horticultura Brasileira, 23(2), 275280. DOI: https://doi.org/10.1590/S0102-05362005000200022

Generoso, T. N., Martinez, M.A., Rocha, G.C., Hamakawa, P.J. 2017. Water magnetization and phosphorus transport parameters in the soil. Revista Brasileira de Engenharia Agrícola e Ambiental, 21(1), 9-13. DOI: https://doi.org/10.1590/1807-1929/agriambi.v21n1p9-13.

Gould, W.A. 1974. Tomato production, processing and quality evaluation, first ed. The AVI, Westport.

IAL. INSTITUTO ADOLFO LUTZ. 2008. Métodos físicoquímicos para análises de alimentos. Zenebon, O., Pascuet, N.S., Tigela, P. (orgs), quarta ed, Instituto Adolfo Lutz, São Paulo.

Khoshravesh, M., Mostafazadeh-Fard, B., Mousavi, S.F., Kiani, A.R. 2011. Effects of magnetized water on the distribution pattern of soil water with respect to time in trickle 
irrigation. Soil Use and Management, 27(4), 515-522. DOI: https://doi.org/10.1111/j.1475-2743.2011.00358.x.

Lopes, S.M., Alcantra, E., Rezende, R.M., Freitas, A.S. 2018. Avaliação de frutos de pimentão submetidos ao ensacamento no cultivo orgânico. Revista da Universidade Vale do Rio Verde, 16(1), 1-11. DOI: https://doi.org/10.5892/ruvrd.v16i1.4922.

Lorenzoni, M.Z., Rezende, R., Souza, A.H.C., Seron, C.C., Gonçalves, A.C.A., Saath, R. 2020. Growth and development of bell pepper crop irrigated with magnetically-treated water. Revista de Agricultura Neotropical, 7(2), 9-16. DOI: https://doi.org/10.32404/rean.v7i2.4173.

Lorenzoni, M.Z., Rezende, R., Souza, A.H.C., Seron, C.C., Hachmann, T.L., Freitas, P.S.L., 2016. Response od bell pepper crop fertigated with nitrogen and potassium doses in protected environment. Agrotechnology, 5(3), 148-152. DOI: https://doi.org/10.4172/2168-9881.1000148.

Maheshwari, B.L., Grewal, H.S., 2009. Magnetic treatment of irrigation water: Its effects on vegetable crop yield and water productivity. Agricultural Water Management, 96, 1229-1236. DOI: https://doi.org/10.1016/j.agwat.2009.03.016.

Mostafazadeh-Fard, B., Khoshravesh, M., Mousavi, S.F., Kiani, A.R. 2011. Effects of magnetized water and irrigation water salinity on soil moisture distribution in trickle irrigation. Journal of irrigation and drainage engineering, 137(6), 398-402. DOI: https://doi.org/10.1061/(ASCE)IR.1943-4774.0000304.

Ospina-Salazar, D.I., Benavides-Bolaños, J.A., Zúñiga-Escobar, O., Muñoz-Perea, C.G., 2018. Photosy nthesis and biomass y ield in Tabasco pepper, radish and maize subjected to magnetically treated water. Corpoica Ciencia Tecnologia Agropecuaria, 19(2), 307-321. DOI: https://doi.org/10.21930/rcta.vol19_num2_art:537.
Putti, F.F., Gabriel Filho, L.R.A., Klar, A.E., Cremasco, C.P., Ludwig, R., Silva Junior, J.F., 2013. Desenvolvimento inicial da alface (Lactuca sativa L.) irrigada com água magnetizada. Cultivando o saber, 6(3), 83-90. https://www.fag.edu.br/upload/revista/cultivando_o_saber/526 e65821f322.pdf

Sayed, H.E.S.A.E., 2014. Impact of magnetic water irrigation for improve the growth, chemical composition and yield production of Broad Bean (Vicia faba L.) plant. American Journal of Experimental Agriculture, 4(4), 476-496. DOI: https://doi.org/10.9734/AJEA/2014/7468.

Seron, C.C., Rezende, R., Lorenzoni, M.Z., Souza, A.H.C., Gonçalves, A.C.A., Saath, R. 2019. Irrigation with water deficit applying magnetic water on scarlet eggplant. Revista de Agricultura Neotropical, 6(4), 1-9. DOI: https://doi.org/10.32404/rean.v6i4.3809.

Souza, A.H.C., Rezende, R., Seron, C.C., Lorenzoni, M.Z., Nascimento, J.M.R., Lozano, C.S., Nalin, D., Terassi, D.S., Gonçalves, A.C.A., Saath, R., Freitas, P.S.L., 2019. Evaluation of the growth and the yield of Eggplant crop under different irrigation depths and magnetic treatment of water. Journal of Agricultural Science, 11(17), 35-43. DOI: https://doi.org/10.5539/jas.v11n17p35.

Surendran, U., Sandeep, O., Joseph, E.J., 2016. The impacts of magnetic treatment of irrigation water on plant, water and soil characteristics. Agricultural Water Manegement, 178, 21-29. DOI: https://doi.org/10.1016/j.agwat.2016.08.016.

Trani, P.E., 2014. Calagem e adubação para hortaliças sob cultivo protegido. (Nota técnica) Instituto Agronômico de Campinas, Centro de Horticultura, São Paulo. https://www.codeagro.agricultura.sp.gov.br/arquivos/hortalim ento/Calagem_e_adubacao_para_hortalicas_201588bf89e2deb 32d9ac52a0ac416664009.pdf. (acessado 14 de março de 2021) 